\title{
42. A SUMMARY OF THE SEDIMENTOLOGY OF DEEP SEA DRILLING PROJECT LEG 67 SITES: THE MIDDLE AMERICA TRENCH AND SLOPE OFF GUATEMALA- AN ACTIVE MARGIN TRANSECT ${ }^{1}$
}

\author{
William T. Coulbourn, Deep Sea Drilling Project, Scripps Institute of Oceanography, \\ University of California, San Diego, La Jolla, California \\ Reinhard Hesse, Department of Geological Sciences, McGill University, 3450 University St., Montreal, \\ PQ Canada H3A 2A7, and Technische Universität, Lichtenbergstrasse 4, 8046 München, West Germany \\ Jacques Azema, Universite Pierre et Marie Curie, Laboratoire de Géologie Structurale, 4 Place Jussieu, \\ Paris 75230 , France \\ and \\ Tsunemasa Shiki, Department of Geology and Mineralogy, Kyoto University, Kyoto, Japan
}

\begin{abstract}
The transect of drill sites across the Middle America Trench offshore Guatemala contains portions of the sedimentary record from the Early Cretaceous to the Recent. Hemipelagic muds cover both slopes of the Trench; the thick accumulation on the Cocos Plate indicates transport of these sediments hundreds of kilometers seaward of their landward-slope source area. Beneath those muds, the sedimentary section of the Cocos Plate is a classic, basalt-chalk-abyssal clay sequence that records the passage of Site 495 from the East Pacific Rise to depths greater than the calcite compensation depth.

The eight holes drilled at Sites 499 and 500 contain portions of the sequence cored at Site 495 , only the abyssal red brown clays of Site 495 are completely missing and a deposit of turbidites caps the hemipelagic muds originally deposited seaward of the Trench. A horst is buried beneath the turbidites ponded in the Trench axis. Facies changes are absent within the turbidites, and biogenic components indicate transport from upslope.

The sediments, sedimentary features, and microfossils cored from the landward slope generally indicate deposition beneath nutrient-rich equatorial waters and subsequent downslope displacement. Tranquil accumulation was interrupted by deposition of pebbly conglomerates at Sites 496 and 497 . Sigmoidal veinlets are common and probably formed as the slope sediments dewatered. Numerous gas voids and greatly expanded core sections characterize these samples. Gas hydrates occurred in the deeper sandy layers at both sites. Beneath the blanket of hemipelagic mud at Site 494, deposits older than the Miocene have a varied lithology and an age sequence reminiscent of deposits outcropping on the Nicoya Peninsula of Costa Rica. The differences between the lithologic section at Site 498 (drilled just to the east of Site 494) and the section at Site 494 indicate that the structure of the lower slope is more complicated than suggested by interpretive models derived from geophysical data. The lithology at both Sites 494 and 498 puts severe restrictions on the volume that an accretionary prism can occupy offshore Guatemala, the type locality for the Trench-Slope Model.
\end{abstract}

\section{INTRODUCTION}

Modern active continental margins are among the geologically least known areas on the globe. Unlike passive continental margins they have not been a prime target for hydrocarbon exploration, because the structural complexities of these zones have evaded successful resolution by seismic reflection profiling and because of low hydrocarbon potential (perhaps a result of depressed geothermal gradients). Great water depth and irregular bathymetry complicate conventional sampling methods. Most theories regarding tectonic processes at convergent margins, therefore, are speculative and are based on geophysical surveys and widely scattered core samples.

One popular hypothesis is that of Seely, Vail, and Walton (1974), the "Trench-Slope Model," which depicts convergent margins as the product of progressive offscraping of sediment and rock from the surface of the subducting oceanic lithospheric plate (Fig. 1). The

\footnotetext{
${ }^{1}$ Aubouin, J., von Huene, R., et al., Init. Repts. DSDP, 67: Washington (U.S. Govt. Printing Office).
}

concept is important to our story because it is based primarily on Exxon seismic reflection data and drilling results from a well on the Guatemalan margin. According to this interpretation, the Guatemalan margin resembles most other convergent margins in that it is an "accretionary prism" (Karig and Sharman, 1975). The concept explains the sequence of landward-dipping reflectors observed on multichannel profiles (Ladd et al., this volume) and the geometry of fore-arc basins common to convergent margin settings (Seely, 1979).

Geological and geophysical results, however, do not lend universal support to this concept. For example, computations of sediment budget and convergence rates, and seismic refraction surveys of sections of the PeruChile subduction zone fail to support the Trench-Slope Model (Katz, 1971; Scholl et al., 1977; Hussong et al,, 1976; Shepherd, 1979). The first results from IPOD convergent margin drilling off Japan and the Marianas have further complicated the picture. The results from Legs 56 and 60 were surprising in that offscraped sediment and rock were not found in the fore-arc setting, greatly reducing the volume that a hypothetical accretionary prism might occupy (von Huene et al., 1980; 

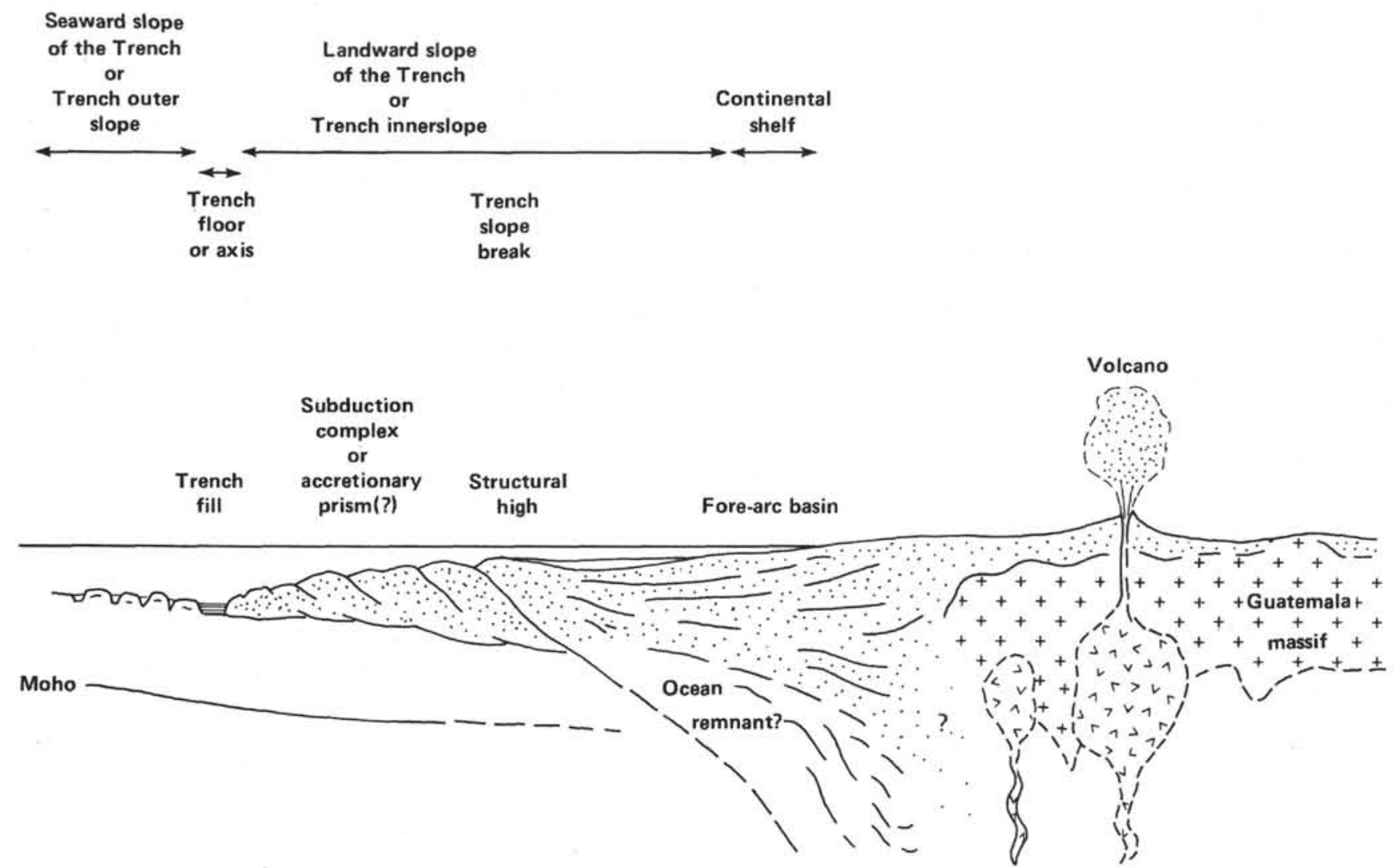

Figure 1. Trench-Slope Model. (The drawing and terminology are adapted from Seely et al. [1974] and Dickinson and Seely [1979].)

Hussong et al., 1982). A summary of lithologic sequences illustrates some of the drilling results from similar tectonic settings (Coulbourn, Introduction, this volume). Where pelagic sediment has been sampled, at Sites 127 (in the Hellenic Trench) and 460 (on the landward slope of the Mariana Trench), its provenance is unclear. Likewise, sands drilled from the landward slope of the Nankai Trough at Site 298 and from the landward slope of the Middle America Trench at Leg 66 sites were perhaps raised from the Trench axis, as Karig et al. (1975) and as Moore et al. (1979) propose, but perhaps were simply ponded in catchments on the slope and never reached the Trench axis. Drilling has not yet achieved the goal of penetration of a complete stratigraphic section through to the subducting oceanic lithospheric plate.

Earthquake foci define the Benioff zone and the active continental margin of Central America (Minster and Jordan, 1978; Carr et al., 1974) where the descending Cocos Lithospheric Plate forms the Middle America Trench and is associated with active volcanism (Fig. 2). How do sediment and rock caught between the volcanic arc and the subducting plate respond to plate convergence? Their distribution within the continental margin may restrict some of the hypotheses describing convergent margin tectonics. The landward dipping reflectors seen on multichannel seismic profiles are not in themselves proof of accretion (Fig. 3). Thick sections of deformed hemipelagic sediment, the absence of pelagic sediment, and the presence of microfauna reworked from upslope would suggest that a variety of "tectonic erosion,"' perhaps as advocated by Hussong et al. (1976) and Scholl et al. (1977), could be applied to the Guatemalan margin. Repeated lithologic and age sequences could document either imbricate thrusting or slumping. Recovery of pelagic sediment in slope sediments, however, would imply the transfer and incorporation of those sequences into a deforming, accreting prism.

The Guatemalan continental margin is a suitable place to pursue these questions. Precruise site surveys located a pronounced sequence of landward-dipping seismic reflectors thought to represent a stack of imbricate rock and sediment (Ladd et al., 1978; Ibrahim et al., 1979; and Fig. 3). We expected the incoming foraminifer-nannofossil chalk riding on the Cocos Plate to contrast with the diatomaceous hemipelagic muds deposited beneath the zone of coastal upwelling. We anticipated that the diversity of tropical microfossil assemblages should afford easy resolution of stratigraphic reversals. And the opportunity to drill offered us once again the chance of penetrating to the subducting oceanic slab.

During Leg 67, 15 holes were drilled at 7 sites located in three tectonic environments: Holes 496, 497, 498, 498 A, 494, and 494A (in order of increasing water depth) on the continental slope, Holes 499, 499A, 499B, 499C, 499D, 500, 500A, and 500B on the floor of the Middle America Trench, and Hole 495 located on the Cocos Plate (see Fig. 4).

\section{GEOLOGIC SETTING}

The Middle America Trench is a major feature of the eastern Pacific ocean basin. Having a length in excess of $2500 \mathrm{~km}$, a width of about 5 to $15 \mathrm{~km}$, and in places 


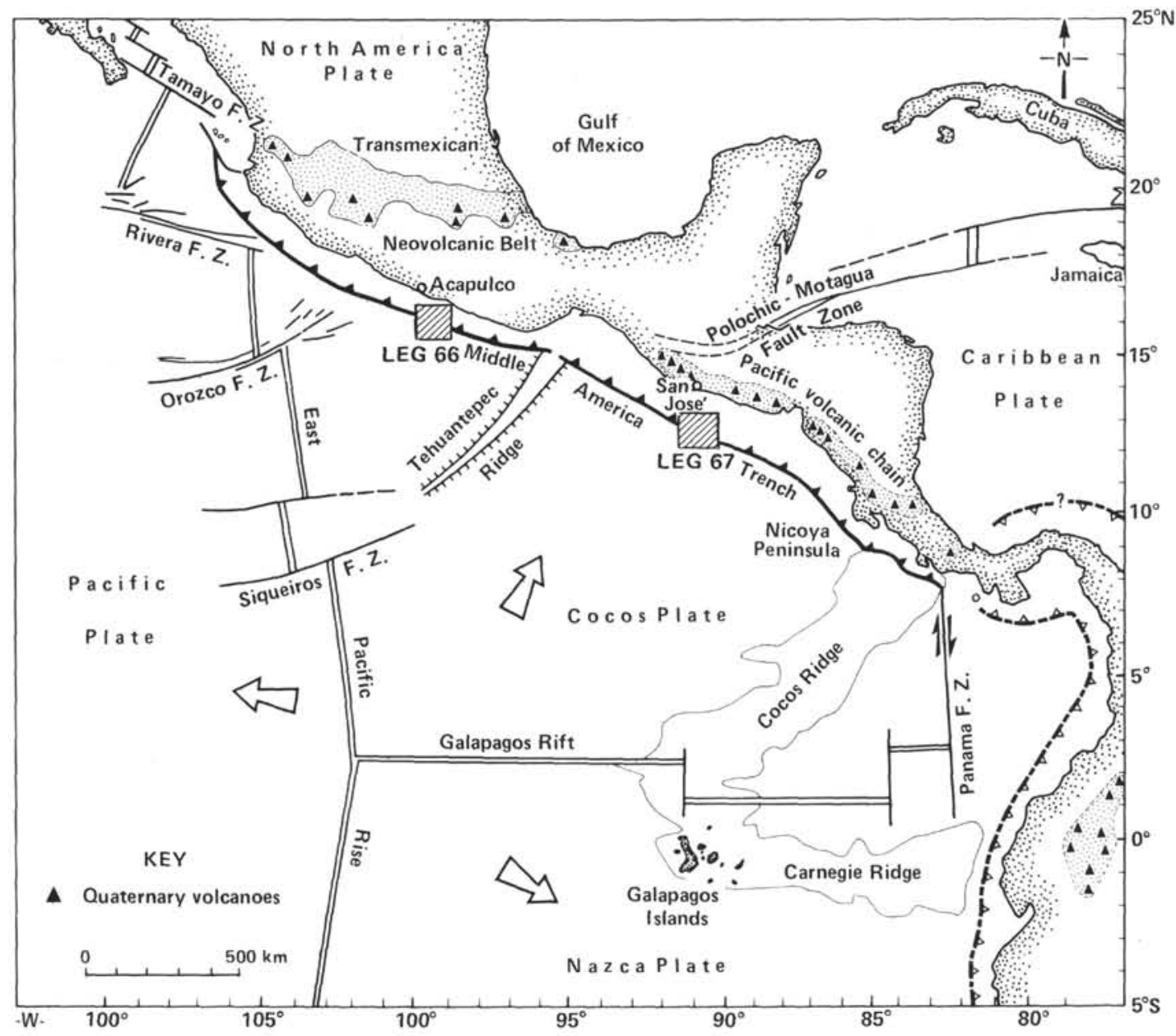

Figure 2. Major tectonic features of Central America and the Middle America subduction zone.

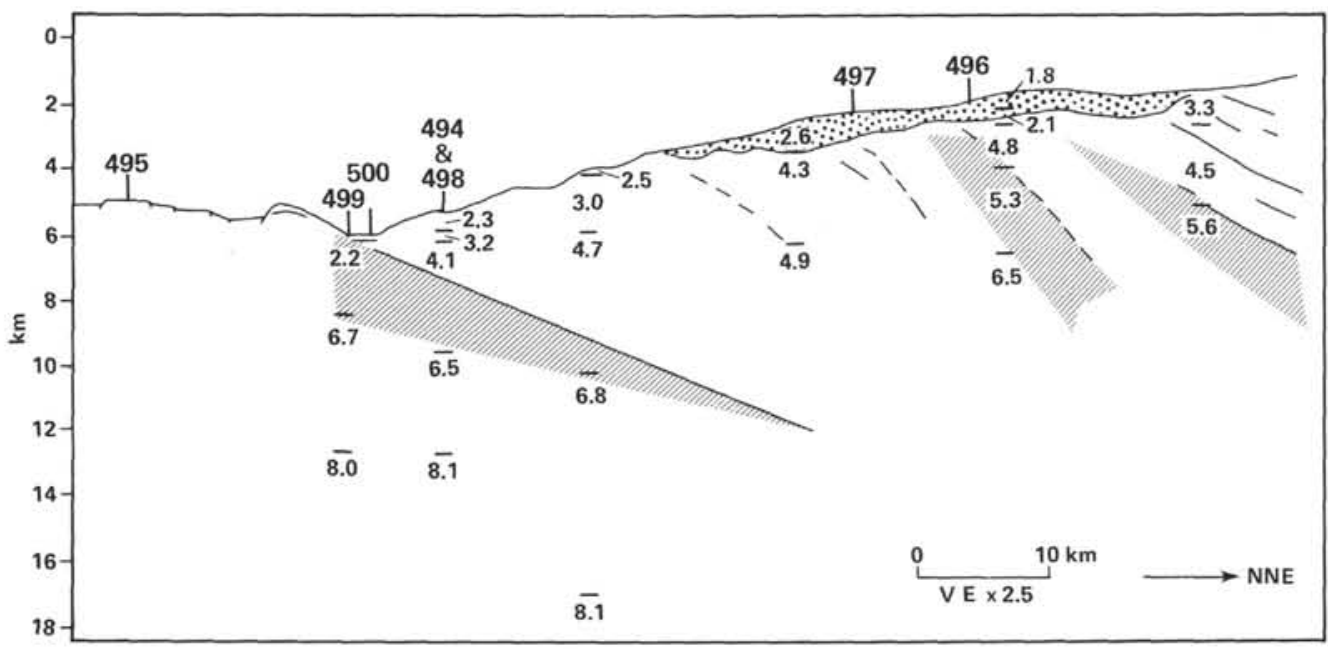

Figure 3. Summary of seismic-reflection and -refraction data off Guatemala, and location of Leg 67 drill sites (after Ladd et al., this volume). (The profile shown is a depth section from multichannel seismic line GUA-13. Numbers refer to refraction velocities, and shaded patterns represent the possible location of oceanic crust. Vertical exaggeration (VE) is $\times 2.5$.) 


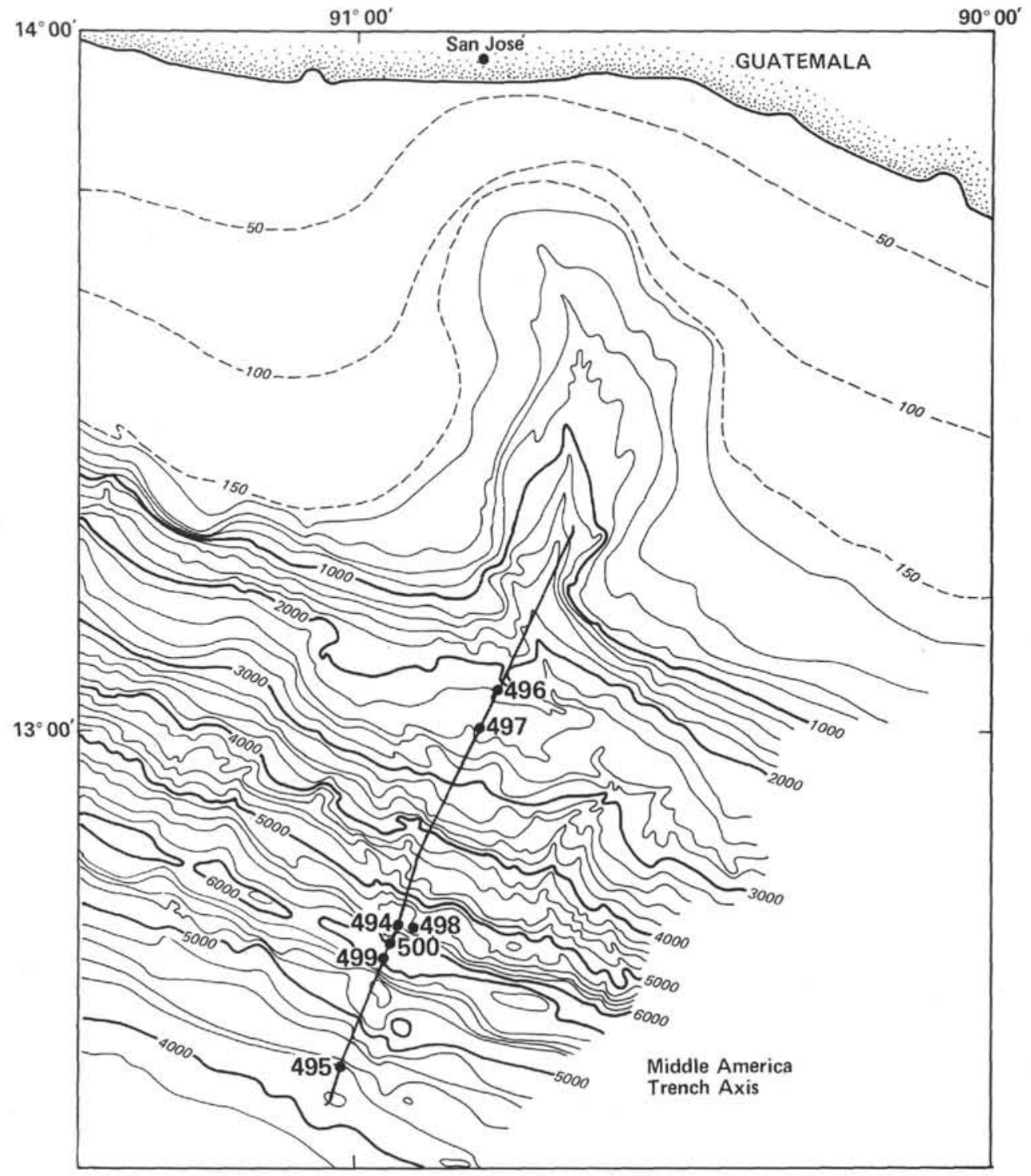

Figure 4. Location of Leg 67 drill sites with respect to the bathymetry of the Guatemalan continental margin.

reaching water depths as great as 6000 meters, it is a composite of two geologic provinces (Aubouin, Azéma, et al., this volume). Along its northern segment the Trench borders southern Mexico, the southernmost part of the North American continent, whereas along its southern part it borders the Central America isthmus, a volcanic chain. As Coats (1962) illustrated in his general diagram relating volcanism and subduction, the volcanism in Central America is probably linked to the subduction of the Cocos Plate.

The Middle America Trench is bordered to the north by the Tamayo Transform Fault and to the south by the aseismic Cocos Ridge (Fig. 2). The Tehuantepec Ridge bisects the Trench, and although it is a major feature of the Cocos Plate, it has no obvious expression in the structural trends of southern Mexico. The North American continent probably extends as far south as the Polochic and Montagua fault zones in Guatemala and perhaps even as far as the Honduran platform. The por- tion of the Trench to the north of the Tehuantepec Ridge cuts the structural trends of Mexico obliquely and borders a very narrow continental shelf. In contrast, the southern portion of the Trench parallels the Mesozoic structural trends of Central America and borders a very wide continental shelf, perhaps formed by the prolongation towards the northwest of formations like those of the Nicoya Complex, exposed on the Santa Elena Peninsula of Costa Rica. Like the Tehuantepec Ridge, the Polochic-Montagua Fault Zone of Guatemala is truncated by the Middle America Trench and has no obvious extension onto the adjacent lithospheric plate.

The contrast between the northern and southern segments could result from the westward movement of both the North and South American lithospheric plates relative to the Caribbean Plate. The extent of the western edge of the Caribbean Plate is perhaps related to this wide section of continental margin. Whatever the cause, the difference between the northern and southern parts 
of the Middle America Trench has been confirmed by drilling transects of Legs 66 and 67 (Aubouin et al., 1979).

\section{MINERALOGIC COMPOSITION AND LITHOFACIES}

During DSDP Leg 67, holes were drilled through the pelagic section of the Cocos Plate at Site 495, through the trench-fill sediments to underlying basalts at Sites 499 and 500, into the lower Trench slope at Sites 494 and 498, and into the middle slope at Sites 496 and 497. The stratigraphy of these drill sites is summarized in Figure 5.

\section{Pelagic and Hemipelagic Sediments of the Cocos Plate (Site 495)}

Site 495 is located on a horst $22 \mathrm{~km}$ seaward of the Middle America Trench axis at 4140 meters water depth and 1915 meters above the Trench floor (Fig. 6). The horst trends $130^{\circ} \mathrm{N}$ to $140^{\circ} \mathrm{E}$ and intersects the strike of the Trench axis at an angle of $15^{\circ}$ to $25^{\circ}$. Similarly, mapping of fault trends for portions of the Nazca Plate revealed oblique intersection of those trends with segments of the Peru-Chile Trench axis (Prince et al., 1974; Coulbourn and Moberly, 1977; Coulbourn, 1981). The Leg 56-57 and the Leg 67 study areas are yet other examples of this geometry (Honza, 1980; Aubouin, Stephan, et al., this volume; Coulbourn, Stratigraphy and Structure of the Middle America Trench, this volume).

Site 495 provides a complete record of pelagic facies successions expected in the eastern equatorial Pacific Ocean. Lithology at this site is based on sharp lithologic changes from basalt, to carbonates, to red brown clays, and finally to olive green hemipelagic muds.

Basalts occupy the sub-bottom interval from 428 to 447 meters (Cores 495-46 to -49) and were formed during a time span of 7 to $8 \mathrm{~m}$.y. at a location near the paleomagnetic equator (Gose, this volume).

A basal sedimentary sequence of 228 meters of lower Miocene pelagic carbonates was rapidly deposited $(50$ $\mathrm{m} / \mathrm{m} . \mathrm{y}$.), indicating an origin beneath the equatorial zone of high productivity. The first core of basalt contained two pieces of very firm, lithified, manganesestained limestone that included fragments of volcanic glass. The basal 22.5 meters of this sequence owe their brown and purplish stain to manganese and iron oxide emanations from ridge-crest hydrothermal activity. The ferromanganese in these chalks often forms dendrites. Lithification and cementation decreases upward; the number of chalk layers decreases and the number of foraminiferal and nannofossil ooze layers per core increases. Siliceous microfossils, radiolarians, diatoms, and sponge spicules are absent in the lower part but common above Core 495-37. This contrast coincides with the first appearance of nodules and thin (less than $5 \mathrm{~cm}$ thick) stringers of chert or porcellanite at the top of Core 38 (352 m sub-bottom). At this level a marked downward decrease occurs in the dissolved silica in the pore fluids, corresponding to its reprecipitation as porcellanite. These calcareous oozes and chalks are biotur- bated except at certain levels in Cores 495-34, -36, and -38 , where distinct primary laminations are preserved. Those laminations attest to the temporary absence of a bottom-dwelling infauna. Accompanying a decrease in sedimentation rates to $16 \mathrm{~m} / \mathrm{m}$.y. near the top of the carbonate unit, colors change from pale green, greenish gray, or very pale bluish green to very pale brown, pinkish white, or light brownish gray in the upper part of the lower Miocene and in the middle Miocene, signalling a further decrease in sedimentation rate as the minimum of $9 \mathrm{~m} / \mathrm{m} . \mathrm{y}$. for the deposition of brown clay is approached. An upward increase in radiolarian content and concomitant loss of foraminiferal biostratigraphic resolution in the carbonate section is due to increased dissolution and corresponds to the subsidence predicted for a lithospheric plate as it moves away from a spreading center (Sclater et al., 1971).

Other components of the clay-size fraction of the pelagic carbonate invariably include mixed-layer smectite-illite and traces of illite (Heinemann and Füchtbauer, this volume; Latouche and Maillet, this volume). Zeolites, feldspar, quartz, and volcanic glass occur in the silt-size fraction. The number of volcanic glass layers reaches one of three maxima near the boundary between the lower and middle Miocene (Cadet et al., this volume). The boundary between the chalk and overlying clay units occurs in Core 495-19 and is marked by color and compositional changes (Fig. 7), a drop in density and shear strength, an increase in water content, and a change from over- to undercompacted sediment (Faas, Gravitational Compaction Patterns chapter, this volume). A small reverse fault, of less than $1 \mathrm{~cm}$ displacement, occurs in Section 495-30-1.

Seven meters of brown abyssal clay cap the pelagic carbonates. According to radiolarian-based age determinations, the ridge flank subsided beneath the calcite compensation depth (CCD) in the middle Miocene. Age data from poorly preserved calcareous nannofossils and foraminifers also date Core 19 as middle Miocene. Mineralogically, sediments of this core contain the same clays as the carbonate unit, but with the addition of kaolinite, abundant volcanic glass, only traces of feldspar and quartz, and complete absence of zeolites (Heinemann and Füchtbauer, this volume). The equivalent present-day area of brown abyssal clay sedimentation is north of the tropical carbonate belt at about $10^{\circ} \mathrm{N}$ to $15^{\circ} \mathrm{N}$ latitude.

A cover of 171 meters of diatomaceous, green and olive gray, hemipelagic mud completes the section. The appearance of these kaolinite, illite, and mixed-layer clay-bearing muds announces the arrival of density flows, suspension clouds, or nepheloid layers at Site 495 . These sediments arrived at Site $\mathbf{4 9 5}$ in the middle Miocene and predate an increased abundance of volcanic glass in the late Miocene (Cadet et al., this volume; Heinnemann and Füchtbauer, this volume). That volcanic glass presumably marks the onset of volcanism in Guatemala and Nicaragua. By the early Pliocene, coarse silt-size grains were accumulating at Site 495 (Shiki, et al., this volume). In some cores, for example, Core 495-4, the terrigenous sediment fraction, composed of feldspars, 

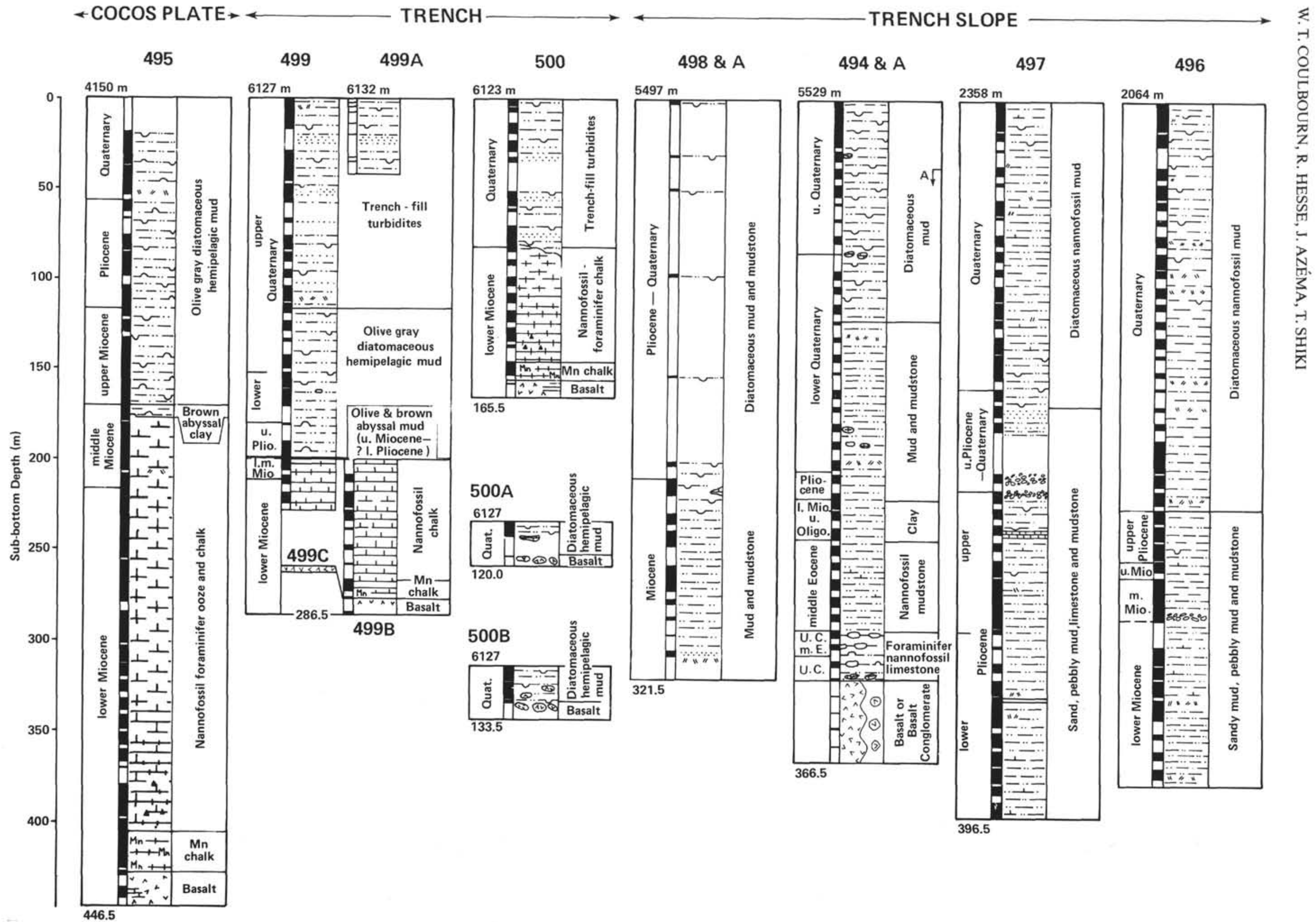

Figure 5. Simplified stratigraphic columns summarizing the lithostratigraphy, biostratigraphy, and recovery of Leg 67 drill sites. 


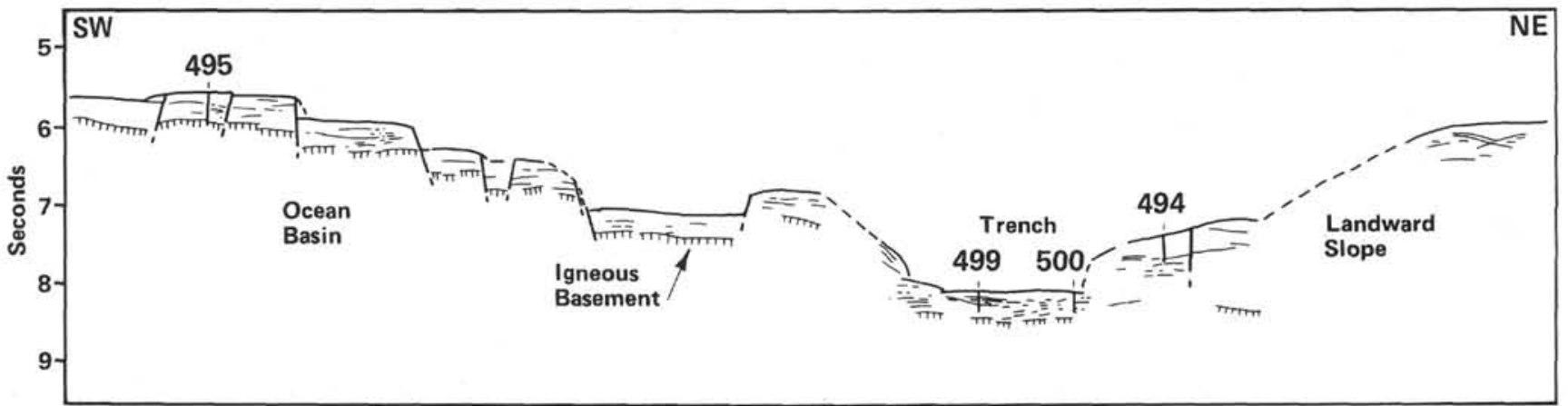

Figure 6. Structure of the Middle America Trench axis as interpreted from seismic reflection record GUA-13 (von Huene, Aubouin et al., 1980):

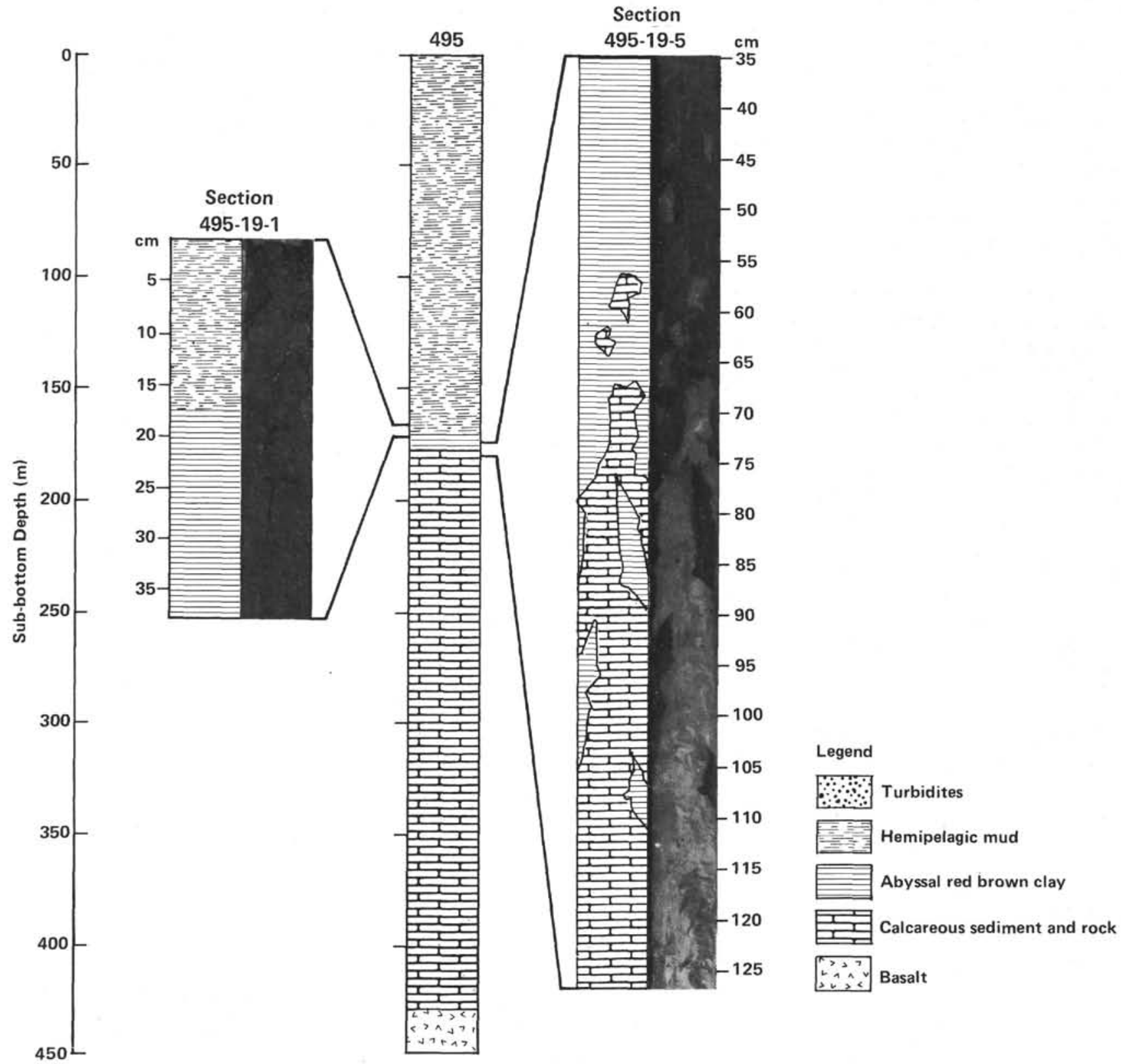

Figure 7. Lithology of Core 495-19. (Hemipelagic clays overlie abyssal brown clays, which in turn overlie pelagic carbonates.) 
volcanic glass, detrital clay minerals, and quartz, predominates. The frequency of occurrence of ash layers reaches a maximum of $15 \mathrm{~m} / \mathrm{m} . \mathrm{y}$. in the Pleistocene sediments (Cadet et al., this volume). These new components boost the sedimentation rate from $9 \mathrm{~m} / \mathrm{m} . \mathrm{y}$. in Core 19 to about $41 \mathrm{~m} / \mathrm{m} . \mathrm{y}$. in the Pliocene and Quaternary cores from Site 495 . Another small reverse fault, like its counterpart in Section 495-30-1, occurs in Section 495-17-6, and its origin is also attributed to softsediment deformation.

The biogenic fraction of the uppermost lithologic unit contains abundant diatoms, radiolarians, sponge spicules, and lesser amounts of calcareous nannoplankton and foraminifers. The upper Miocene to Pliocene sediments in Cores 14 to 18 also contain cold water diatoms diagnostic of neritic upwelling zones (Jousé et al., this volume). The appearance of lower bathyal, calcareous benthic foraminifers suggests a slight shallowing of the sea floor as the site approached the outer swell of the Trench. Coincident with that relatively exposed position, radiolarian stratigraphy indicates that the uppermost two radiolarian zones are missing, probably because of erosion (Westberg and Riedel, this volume).

\section{Turbidites, Pelagic and Hemipelagic Sediments of the} Middle America Trench Axis (Sites 499 and 500)

The network of eight closely spaced holes drilled at Sites 499 and 500 provides a unique data base for the sedimentary sequence in the Trench. We are able to state that the surface of the Cocos Plate is offset by normal faults as it enters the Trench and that the sedimentary section it carries into the subduction zone is passively buried beneath a wedge of axial turbidites (Aubouin, Stephan, et al. this volume; Coulbourn, Stratigraphy and Structure, this volume). Compressive structural features are absent, even at the foot of the continental margin. Also absent are veinlets, scaly fractures, and other fabric that might account for significant compression registered on a small scale.

The lithologies at Site 499 match those at Site 495, our reference site for pelagic sedimentation, except for the addition of a cover of trench-fill deposits, specifically, interbedded turbidites and hemipelagic muds. As at Site 495 , lithology at Sites 499 and 500 shows abrupt changes. The succession of pelagic sediment facies overlying rubbly basalt includes calcareous chalk and ooze overlain by burrow-mottled hemipelagic muds. The calcareous section at Site 499 is only one-third the thickness of that at Site 495 , and solution of foraminifers is more pronounced than at Site 495, indicating deposition nearer the CCD. Pyrite concentrations and the odor of $\mathrm{H}_{2} \mathrm{~S}$, even in the chalky sections, indicates that reducing conditions prevail. The contact between nannofossil ooze and hemipelagic mud occurs in Core 499-23 (Fig. 8 ). No red brown clays comparable to those of Core 495-19 were recovered.

The turbidites are undercompacted (Faas, Gravitational Compaction Patterns, this volume) and include nannofossil muds, laminated sandy muds, muddy sands, and medium to coarse sands. Though drilling distur-

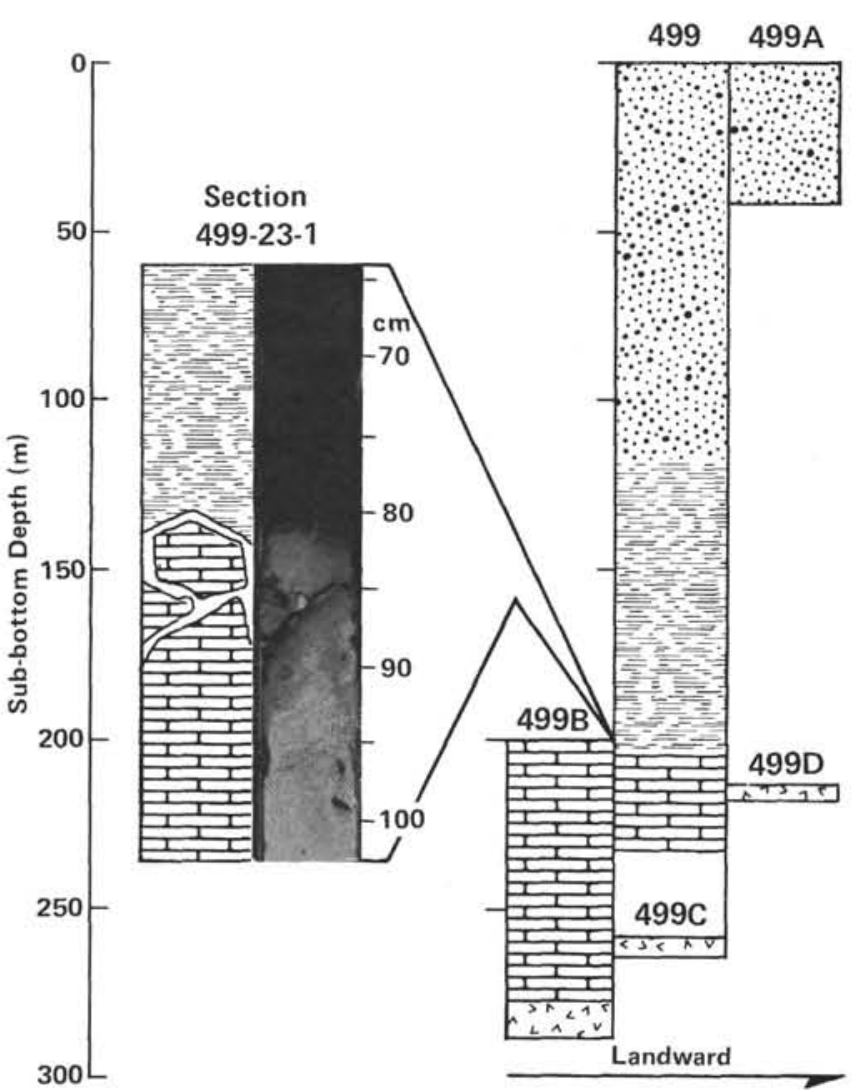

Figure 8. Lithology of Core 499-23. (Sharp contact between hemipelagic clays and pelagic carbonates. The red brown clays of Core 495-19 are missing in the Trench axis lithologic sections. Refer to Fig. 7 for an explanation of symbols.)

bance often obscured sedimentary structures within specific turbidite beds, the systematic change of grain-size distributions in each bed of the trench-fill deposits is comparable to that of well-preserved turbidites pistoncored from the Okinawa Trough (Shiki, et al., this volume) and from the Japan Trench (Hesse, 1977). Biogenic components, including wood fragments, diatoms, and benthic foraminifers, indicate rapid transport from upslope. Diatom assemblages include species typical of brackish-water habitats (Jousé, et al., this volume). Benthic foraminifers indicate progressively shallower sources ranging from lower bathyal in cores deeper than Core 499A-12, to upper bathyal in Cores 499-1 to -9 , to upper shelf fauna in Cores 499-1 to -7 and Cores 499A-1 to -5 (Thompson, this volume). Rapid accumulation $(300 \mathrm{~m} /$ m.y.), preserving a high concentration of organic matter, is probably responsible for the $\mathrm{H}_{2} \mathrm{~S}$ odor, and that gas content in turn could generate the undercompaction registered in the physical properties analyses (Faas, Gravitational Compaction Patterns, this volume).

The heavy mineral composition of the sand fraction contains hypersthene, augite, green brown hornblende, and lesser amounts of epidote and olivine. This mixture strongly resembles that deposited in the Quaternary and Pliocene samples from Site 494, located on the lower slope. The pyroxenes and amphiboles, which together 
constitute more than $90 \%$ of the heavy mineral concentrates, are present in an average 3:1 ratio (Prasad and Hesse, this volume).

Volcanic glass fragments, labradoritic plagioclases, and montmorillonite are the dominant components of the silt and clay fractions of Site 499 sediments (Heinemann and Füchtbauer, this volume). Other constituents include zeolites and quartz. The number of ash layers per million years reaches a maximum in the Pleistocene sediments of Site 499 (Cadet et al., this volume), however, all may not be accounted for, as Heinemann and Füchtbauer (this volume) attribute the abundance of zeolites to the alteration of volcanic glass deposited within the Trench axis turbidites. Kaolinite and illite do not appear before the late Pliocene, whereas at Site 495 on the Cocos Plate they occur as early as the middle Miocene. This discrepancy may be a sampling artifact, because no middle Miocene, late Miocene, or early Pliocene samples were analyzed for the Trench sites.

The lithologies at Site 500 are basically the same as at Site 499 , however, basalt cobbles were found at relatively high levels within the hemipelagic mud at Holes 500A and 500B. A contact between Quaternary turbidites filling the Trench axis and underlying middle Miocene foraminifer-nannofossil ooze in Section 500-10-2 is probably the result of normal faulting; in this process the hemipelagic sediments have been cut out of the stratigraphic sequence (Fig. 9). Cobbles of micritic limestone were also recovered at high levels at Hole 500A (105 m sub-bottom), and benthic foraminifers indicate transport of sediment to the Trench axis from the entire depth range of the continental margin (Thompson, this volume). Two small reverse faults, of less than $0.5-\mathrm{cm}$ displacement, occur in Section 500-13-2, and one normal fault offsets the foraminifer-nannofossil chalk of Section 500-14-1 (Dengo, this volume).

The geometry of the lithologies encountered in our eight Trench axis holes coupled with the results of a Seabeam survey across the Trench axis demonstrate that the Cocos Plate is broken by a network of normal faults (Aubouin, Stephan, et al., this volume; Coulbourn, Stratigraphy and Structure, this volume). These trends are probably a composite of "tectonic fabric" generated at mid-ocean ridge crests (Rona et al., 1976), reactivation of those faults in mid-Plate settings (Luyendyk, 1970), and, finally, generation of new faults and reopening of old scarps as the Plate bends downward into the subduction zone (Coulbourn, Stratigraphy and Structure, this volume). The time range of possible tectonic movements allows ample chance to disturb an otherwise normal pelagic sedimentary sequence.

\section{Sediments of the Lowermost Continental Slope (Sites 494 and 498)}

Sites 494 and 498 are located on a bench or terrace on the landward side of the Middle America Trench, about 580 meters above the surface of the turbidites ponded in the Trench axis (Fig. 6). Bathymetry suggests that the terrace may be formed as either a slump block, as a block fault, or as a result of a large landward-dipping

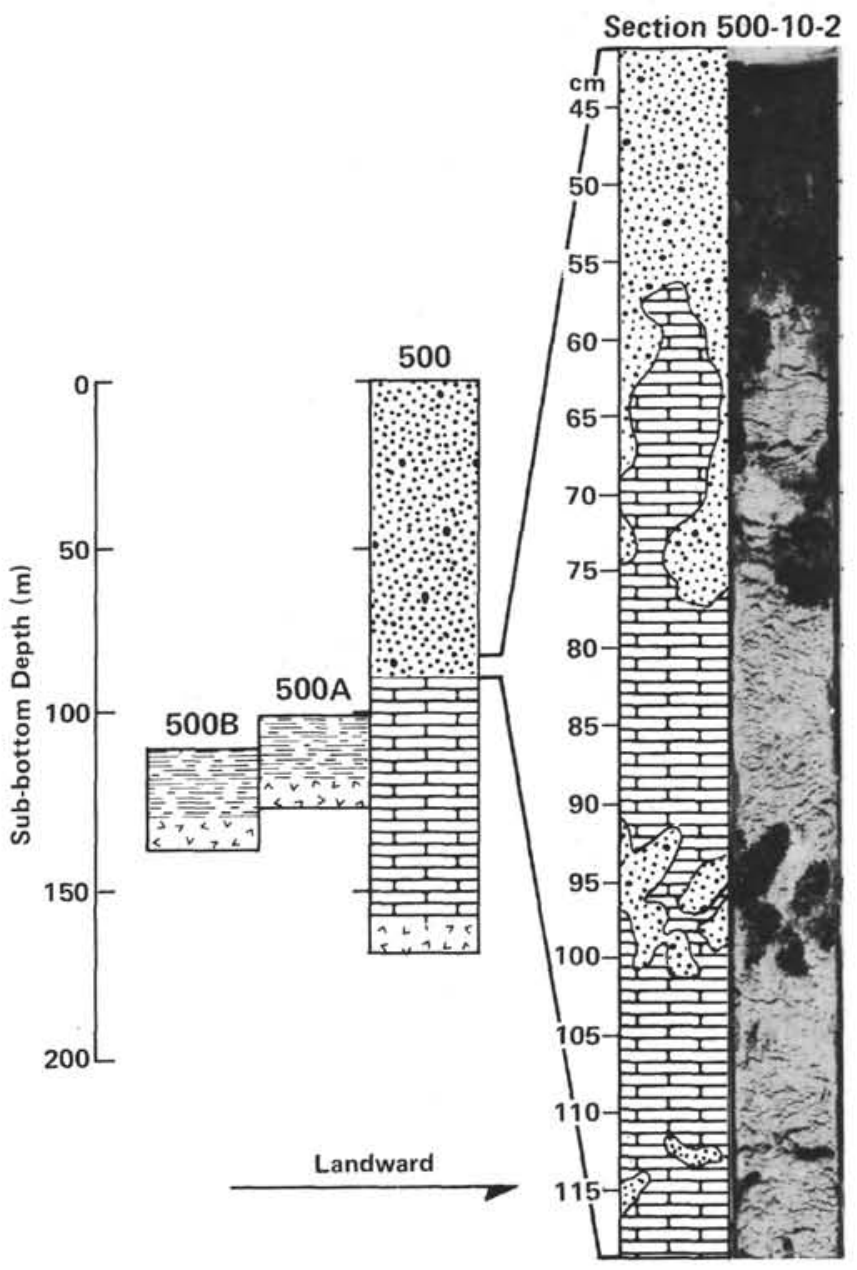

Figure 9. Lithology of Core 500-10. (Contact between Quaternary turbidites filling the Trench axis and underlying foraminifer-nannofossil ooze. See Fig. 7 for an explanation of symbols.)

thrust (Aubouin, Stephan, et al., this volume). The sequence of lithologies recovered does not preclude any of these interpretations.

Drilling at Hole 494A ended with long drilling times and recovery rates of about $3 \%$. Only 1 meter of rock and sediment was recovered in the sub-bottom interval from 321.5 to 366.5 meters (Cores $31-35$ ). The altered mafic and intermediate composition of rocks from these cores, however, raises some important questions about their origin. Their feldspar composition indicates an "active margin basalt parentage," but their depletion in the Rare Earths is typical for oceanic tholeiites; their origin therefore remains problematic (see Maury et al., this volume).

Late Cretaceous medium gray mudstone composes most of the drill breccia in Core 30 (312.5-321.5 m subbottom). Some of these pebbles contain relatively diverse foraminiferal assemblages, including Globotruncana. Benthic foraminifers are sparse, and small planktonic taxa are abundant, indicating deposition under open-marine conditions at depths well above the CCD (Thompson, this volume). Paleomagnetic latitudes aver- 
age $12^{\circ}$ for the Cretaceous samples and suggest that the sediment was deposited near its present-day latitude of $12.7^{\circ} \mathrm{N}$ (Gose, this volume).

A mixture of middle Eocene dark gray mudstone and Late Cretaceous blue gray micritic limestone compose the 3 meters of sediment recovered in Cores 28 and 29 (294-312.5 m sub-bottom). Radiolarians first appear in Core 494A-29 and indicate that Eocene drill chips are a minor component of this mixture (Westberg and Riedel, this volume). The pattern of mixing of Cretaceous and Eocene microfauna could belie a stratigraphic reversal; however, it probably arises from drilling contamination (see Site 494 report core photographs, this volume).

Dark gray middle Eocene mudstone, the likely source of the chips in Cores 494A-28 and -29, were recovered in Cores 22 to 27 drilled from 240 to 294 meters below the seafloor. Recrystallization and poor preservation of foraminifers and relatively abundant calcareous nannofossils suggest that deposition of this unit occurred above the nannofossil lysocline, but below the foraminiferal lysocline (Thompson, this volume). Incipient cleavage in Core 494A-25 and healed fractures in Core 494A-27 provided us some indication of features lost in the many cores of pure drill breccia (Fig. 10).

An unconformity at a sub-bottom depth of 240.5 meters marks the onset of accumulation of a blue gray clay and claystone containing lower Miocene to upper Oligocene nannofossils attributed to open-ocean environments rather than to regions of coastal upwelling (Cores 20-22, 223-240 m sub-bottom). Dengo (this volume) and Faas (Gravitational Compaction Patterns, this volume) discuss the plasticity and remarkable deformational features of these clays.

An unconformity at 223 meters sub-bottom is the base of a blanket of dark gray diatomaceous mud (Cores 494A-1 to -20). Only sediment of the uppermost 50 meters is normally compacted; the interval from 50 to 233

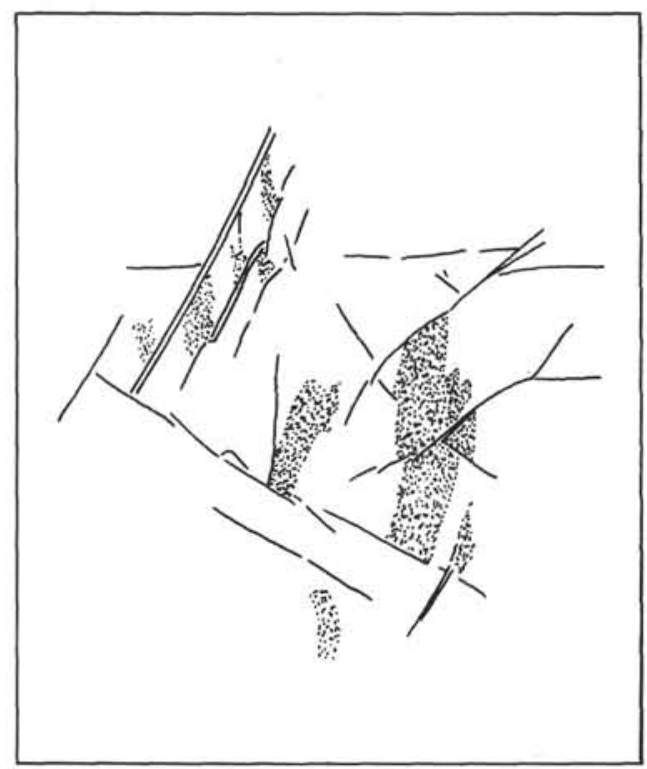

Figure 10. Structure of Section 494A-27-1. (Closely spaced faults offset light gray sandy mudstone [stippled].) meters sub-bottom is overcompacted, and is marked by abrupt increases in density and shear strength and a decrease in water content. Overcompacted sediment at shallow depth can occur by removal of sediment overburden, dessication, or cementation and recrystallization (Faas, Gravitational Compaction Pattern, this volume). The number of ash layers per million years reaches a maximum near the Pliocene/Pleistocene boundary at Cores 494A-16 to -17 (Cadet et al., this volume). During the Pliocene, diatoms representative of tropical assemblages accumulated at Site 494 , while cold water forms, typical of coastal upwelling regions, were accumulating seaward at Site 495 . Benthic foraminifers in this uppermost unit are typical of assemblages normally cored from a water depth of 1000 meters.

Site 498 was drilled in the hope of improving the percentage recovery achieved at Site 494 and in the hope of extending that section to deeper levels. Neither of these aspirations was realized. The uppermost units of olive gray, diatomaceous mud represent a drape of hemipelagic sediment, 213 meters thick, reworked from upslope. As in the uppermost unit at Site 494, there is no evidence that these are turbidites.

Beneath that depth, a heterogeneous sequence of facies documents the complexity of the landward slope of the Middle America Trench. A comparison of the samples recovered at Sites 494 and 498, moreover, documents a lateral variability of structure. The blue gray mudstone found at 213 to 321 meters sub-bottom in Hole $498 \mathrm{~A}$ is the equivalent of that occurring at $213 \mathrm{~m}$ to 241 meters sub-bottom in Hole 494A. The remaining four lithologic units found at Hole 494A are not represented at Hole 498A (494A, 249-358 m sub-bottom). Gas hydrates were encountered in volcanic ash and sand at 310 meters sub-bottom, associations that occurred at Site 496 and again at Site 497 . Figure 11 illustrates the vigorous effervescing of methane-rich gas that prompted us to abandon the hole. Curiously, gas hydrates were not encountered at Site 494 .

\section{Hemipelagic Sediments of Mid-Slope Sites 496 and 497}

Sites 496 and 497 are located at water depths of 2062 meters and 2358 meters, respectively, seaward of a forearc basin in the vicinity of the San José Canyon. The sediments at the two sites are similar, except that the Quaternary deposits are thicker and the Pliocene sediments thinner at Site 496 than at Site 497. Also, drilling at Site 496 reached lower Miocene sediments, whereas at Site 497 drilling reached only lower Pliocene sediments at similar sub-bottom depths. The sediments are olive gray to dark gray, hemipelagic, diatomaceous muds with interbedded volcanic ash that usually occurs in patches and stringers deformed by drilling. Our lithologic subdivisions are based primarily on grain-size changes rather than contrasting sediment composition. At both sites the lower lithologic unit is differentiated from the upper on the basis of downward increasing sand and pebble content.

The lower unit is overcompacted at Site 496 and normally compacted at Site 497 (Faas, Gravitational Com- 


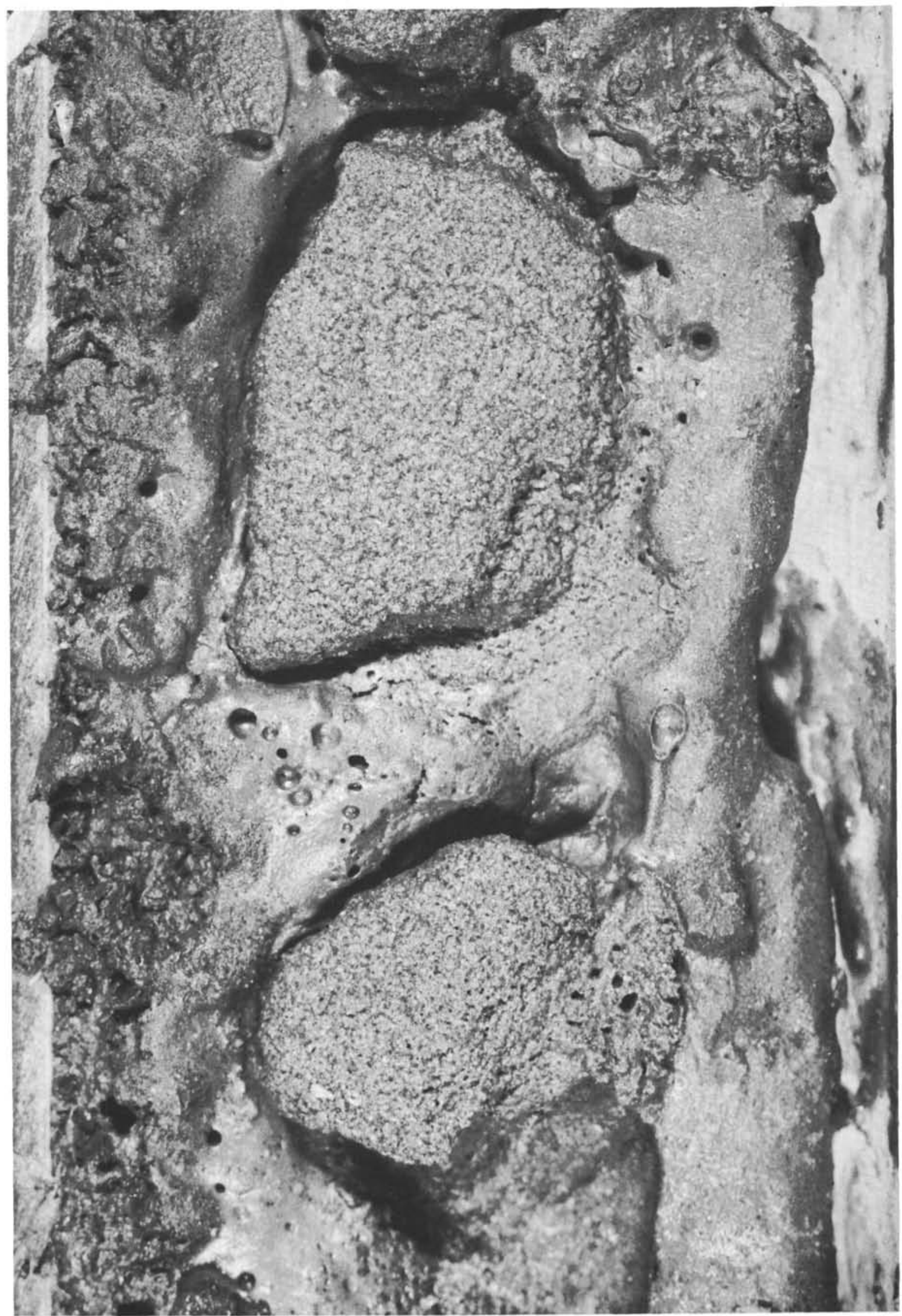

rigure 11. Gas hydrates effervescing from Section 498-15-2 
paction Patterns, this volume). The pebbles occur in indistinctly graded, intraformational pebbly mud and mudstone layers at about 280 meters sub-bottom in the middle Miocene sediments of Site 496 and at about 200 meters sub-bottom in the upper Pliocene sediments of Site 497, and are made up of mud and mudstone intraclasts. The sand grains in the sandy muds include volcanic glass, glauconite, pyrite, numerous fossil remains, feldspar, and rarely quartz. Sands are perhaps underrepresented in our cores by preferential loss during drilling. For example, the recovery of the intraformational pebbly conglomerate in Cores $497-23$ and -24 was preceeded by 19 meters penetration with no recovery. Gas hydrates were particularly noticeable in the coarse layers at the base of both sites but probably occur throughout the entire section at both Sites 496 and 497 (Harrison et al., this volume).

The silts at Site 496 contain generally more than $50 \%$ volcanic glass, the remainder consisting of feldspar and small amounts of quartz, opaline silica, and zeolites (Heinemann and Füchtbauer, this volume). Comparable results are not available for Site 497 . The number of ash layers at both Sites 496 and 497 increased sharply from early Pliocene to Pleistocene (Cadet et al., this volume).

At both Sites 496 and 497, primary sedimentary structures indicative of depositional mechanisms are lacking. The clay fraction consists predominantly of montmorillonite, with some illite and kaolinite occurring in about the same amounts. Chlorite was identified in Core 4963 . In addition, the fine-grained sediments include two thin layers of micrite in Section 497-26-3 and Section 497-36-1. Specimens examined in thin section lacked microfossils and microfossil traces, and resemble the light colored, homogeneous, barren dolomicrites dredged from the Peruvian continental margin (Kulm et al., 1981). Microcrystalline dolomitic nodules were also cored at Sites 434 and 435 on the Japan margin (Okada, 1980) and at Sites 490 and 493 off southern Mexico (Wada et al., 1982). Throughout most of the sections at both sites the populations of benthic foraminifers resemble assemblages accumulating at comparable depths today. Below 308 meters sub-bottom at Site 496, however, the assemblages indicate paleodepths somewhat shallower than their present 2400 meters (Thompson, this volume).

Possible causes for the absence or paucity of sedimentary structures are: (1) bioturbation (rarely identified at Sites 496 and 497, in contrast to Site 495), (2) drilling disturbance (most common), (3) slumping (little evidence at Sites 496 and 497 , in contrast to Site 494), (4) occurrence of gas hydrates and associated sediment degassing, and (5) tectonic deformation evidenced by the development of sigmoidal veins (Fig. 12), scaly clays, and cleavage. Sigmoidal veins that are filled with dark clay appear at about 150 meters sub-bottom and represent a semipenetrative deformational structure caused by or, more likely, causing and enhancing sediment dewatering (Cowan, this volume; Dengo, this volume). These deformation features are not unique to the Guatemalan margin; their similarity to those described from comparable sub-bottom levels at Japan Trench DSDP sites is striking (Arthur et al., 1980).

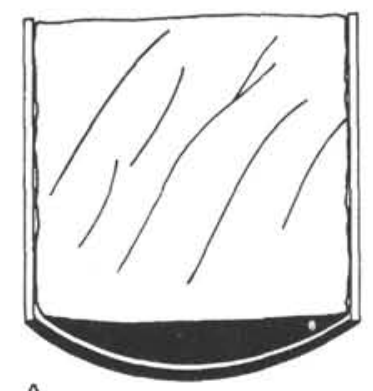

A

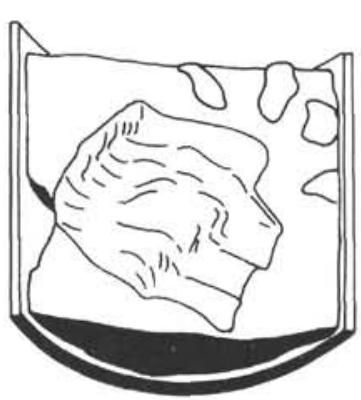

C

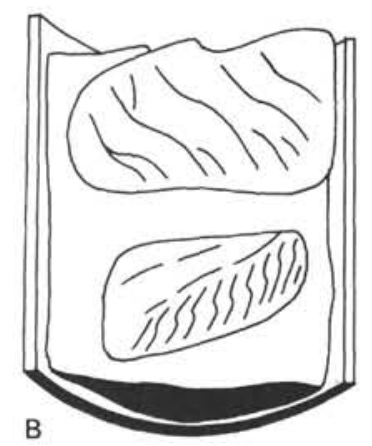

Figure 12. Sketches of veinlet patterns in Site 497 samples. A. Section 497-17-3. B. Section 497-34-2. C. Section 497-36-1. D. Section 497-36-4.

\section{PROVENANCE AND TRANSPORTATION}

The stratigraphy of Leg 67 drill sites documents the reworking of sediment from shallow to deeper slope environments, the redeposition of slope sediments over the pelagic sediments of the Cocos Plate, and the conspicuous absence of graded beds and current bed forms in most of these displaced sediments.

\section{Site 495}

Site 495 is not only $22 \mathrm{~km}$ from the Trench but is also 2000 meters above the Trench floor. At the onset of hemipelagic sedimentation the paleolocation of Site 495 was even more distant from the continental margin. Assuming a spreading rate of $9 \mathrm{~cm} / \mathrm{yr}$. for the last $10 \mathrm{~m} . \mathrm{y}$., hemipelagic sedimentation began when Site 495 was 900 $\mathrm{km}$ seaward of its present position. In terms of presentday sedimentation patterns this distance seems excessive, if the source of sediment is attributed to coastal upwelling. It does not seem excessive, however, if it is attributed to suspended or diluted density currents cascading over the slope, currents that could spread out like a cloud at shallow or intermediate water depths (e.g., Drake and Gorsline, 1973) and extend far enough seaward to deposit this blanket of mud (Shiki et al., this volume; Heinemann and Füchtbauer, this volume). A similar deposit exists east of Japan where a wedge of hemipelagic and volcanogenic silty sediment extends 
seaward at least $800 \mathrm{~km}$ into the West Pacific (Hesse et al., 1974). Whatever the cause may be, the result has the potential of complicating our interpretation of the sedimentary section at other Leg 67 sites, because the hemipelagic section at Site 495 would be virtually indistinguishable from the slope sediments were it mixed tectonically with the hemipelagic drape covering the continental margin.

\section{Sites 499 and 500}

The sharp contact between nannofossil-foraminifer ooze and hemipelagic mud in Core 499-23 contrasts with the sequence shown in Core 495-19 (compare Figs. 7 and 8 ). The absence of red brown clays in the Trench axis holes suggests that nepheloid-layer transport affected the paleolocation of Site 499 at about the same time the site subsided beneath the CCD or that bottom currents had sufficient velocity to erode any red brown clay that had been deposited.

The trench-fill seaward of San José, Guatemala, includes turbidites, hemipelagic sediments, and eupelagic deposits. Except for the pebbly mudstones at Sites 496 and 497 , these are the only drill sites on the Guatemalan transect that have provided clear evidence for the occurrence of sedimentary mass flow deposits such as turbidites. These turbidites contain

1) Components derived from the Neogene volcanic province of Guatemala.

2) Diatoms and benthic foraminifers reworked from nearshore environments.

3) Plant fragments.

These constituents indicate supply from land and possible temporary redeposition on shallower parts of the margin. The unique occurrence of some of these components in turbidites of the Trench floor and the apparent absence of turbidites on the slope, moreover, suggest transportation by "bypassing"' through canyons. San José Canyon, situated close to Sites 499 and 500, is an appropriate conduit for "bypassing." The pebbly mudstone layers encountered at Sites 496 and 497, on the other hand, may indicate spillover of particularly voluminous and vigorous massflows from the nearby canyon to the open slope.

Exotic pebbles were recovered at Sites 499, 500, and 494. The lithologic assemblage includes: peridotites, altered basalts, micritic calcareous rocks, and a quartz diorite pebble. With the exception of the quartz diorite pebble, the assemblage resembles rocks recovered during other oceanographic cruises to the region, suggesting a source in outcrops that may have been exposed once before, as the Nicoya and Santa Elena peninsulas to the south are exposed today.

The quartz diorite pebble was found in Pleistocene sediment (Section 494-16-1), and its occurrence may have a different significance. This rock is poor in potash feldspar, and iron is disseminated throughout. It is, in fact, richer in iron than the rock name suggests. Fractures are well-developed, and the quartz and feldspar grains have wavy or mosaic extinction. Some of the dark minerals, mainly hornblende, also have mosaic extinction characteristic of protoclastic texture. Similar acidic rocks have not yet been observed in the Nicoya Peninsula, however, our sample indicates that at some past time these rocks outcropped along the Guatemalan margin.

\section{Sites 494 and 498}

The mode of emplacement of the rock and sediment at Site 494 is a matter of conjecture. Poor recovery and long sections of drill breccia preclude definite conclusions. The differences in lithologies between Sites 494 and 498 are suggestive of either postdepositional slumping, local tectonic displacement by transverse faulting, variably oriented planes along which imbricate thrusting has occurred, or the chaotic distribution of rocks that might be encountered in a mélange of large proportions.

Neither repeated lithologic and age sequences, pelagic brown clay, nor chalk were encountered at Site 494. The pelagic sediments recovered contain species of nearshore microflora and terrigenous components that indicate a slope position of the entire sequence since the Cretaceous (Muzylöv, this volume; Heinemann and Füchtbauer, this volume). Paleomagnetic results, moreover, indicate that Late Cretaceous rocks cored at Site 494 have not travelled long distances to their present location (Gose, this volume). If accretion and imbrication are occurring at this lowermost part of the slope off Guatemala, the process is limited to the space between the base of Hole 494A and the top of the seismic reflector thought to represent Cocos Plate basalt (Ladd et al., this volume). Based on the interpretation of these multichannel records, that space is 500 to 800 meters thick. Chalks deposited in the early Miocene are now in the Trench axis. Assuming that sediment supply is constant and that subduction has occurred since the time of deposition of the oldest recovered slope sediments (i.e., the Late Cretaceous to early Eocene), some $40 \mathrm{~m}$.y. of time must be contained in the undrilled interval. A substantial amount of pelagic sediment must have been subducted.

Terrigenous sands are absent at Site 494 below 18.5 meters sub-bottom; therefore we lack the evidence for the uplift and incorporation of trench-fill turbidites into the trench slope so strongly advocated by the Leg 66 scientific party (Moore et al., 1979). The lithologic sections of Sites 494 and 498 do not support the "Trench-Slope Model" for convergent margin tectonics as proposed by Seely et al. (1974).

\section{Sites 496 and 497}

The terrigenous, volcanogenic, and pelagic biogenic components of the sediments at Sites 496 and 497 suggest a trench-slope environment having two dominant sediment sources since the early Miocene: the nearby Neogene volcanic province of Guatemala and the biogenic production in surface water layers strongly influenced by upwelling. Upwelling throughout that inter$\mathrm{val}$ is indicated by the abundance and composition of the diatom and nannofossil assemblages. Jousé et al. (this volume), however, report abundant tropical diatoms in Cores 496-1 and -3, suggesting a variable paleoenvironment. High abundance of organic carbon, as 
much as $5 \%$ but on the average $2 \%$, is largely due to land-derived organic matter (Curiale and Harrison, this volume).

As within the uppermost lithologic unit at Sites 494 and $498(0-213 \mathrm{~m}$ sub-bottom $)$, there is no evidence of graded beds at Sites 496 and 497, except in the pebbly mudstones. Microfaunal and microfloral populations indicate varying degrees of downslope reworking of this sediment drape (Jousé et al., this volume; Muzylöv, this volume; Thompson, this volume) Similarly, Bein and Fütterer (1977) found evidence for downslope reworking coupled with absence of bed forms in sediments of the passive continental margin of northwestern Africa. They invoked McCave's (1972) suggestion of reworking by currents and cascades of lutite flows and Seibold's (1976) combination of resuspension through bioturbation and downslope gravity transport as possible mechanisms. Our results suggest that mechanisms such as these may also exert the most dominant influence on the sedimentary drape of the active continental margin of Guatemala.

\section{DIAGENESIS}

Detailed mineralogic study of the clay- and silt-sized fractions (Heinemann and Füchtbauer, this volume) has revealed few mineralogical changes attributable to diagenetic reactions. Optical investigation of glass shards did not show signs of smectitization. On the other hand, the mixed-layer smectite-illite minerals present in the lower to middle Miocene pelagic carbonates of Site 495 must have formed by the alteration of volcanic glass. It is possible, therefore, that small glass shards, few microns in diameter, were the main source of the swelling clay minerals in the Miocene and also in the younger hemipelagic sediments. Also, the zeolites found in most samples of the silt fraction are likely a diagenetic product (Heinemann and Füchtbauer, this volume). Disappearance of olivine in the heavy mineral concentrates of the sand fraction in Miocene sediments of Hole 498A suggests intrastratal dissolution of mafic minerals (Prasad and Hesse, this volume). The only other mineralogic effect of early diagenetic processes is the formation of lutitic limestones as a by-product of organic matter decay and pyrite formation.

Whereas mineral reactions during early diagenesis are sluggish, particularly in a relatively cold geothermal environment, the organic-matter-rich hemipelagic sediments encountered on the trench slope at Sites 496 and 497 undergo pronounced alterations. Those changes result from the oxidation of organic matter, a process most rapid in the upper 50 to 100 meters of the sediment column. Oxidation is reflected by strong gradients in the pore-water compositions of the rapidly deposited sediments. The dramatic rise in alkalinity observed in the upper 25 to 50 meters of Holes 496 and 497, reaching a maximum of $120 \mathrm{meq} / 1$ at 22 meters sub-bottom depth in Hole 496, is the immediate consequence of this oxidation process (Harrison et al., this volume). This alkalinity increase occurs after sulfate depletion; it is therefore associated with deeper zones of organic matter oxidation, in which methane is produced.
The concentration of magnesium in the interstitial waters of Holes 496 and 497, after a rapid initial increase due to release from swelling clays by cation-exchange for $\mathrm{NH}_{4}$, decreases downward in the holes, probably reversing the clay-exchange reaction. Dolomite formation would also serve as a sink for $\mathrm{Mg}^{+2}$, but no dolomite was identified in the sediment samples. The concentrations of $\mathrm{Cl}^{-}, \mathrm{Na}^{+}$, and, to a lesser extent, $\mathrm{K}^{+}$ decrease downhole. Calcium, however, does not show the expected downward increase. These variations add up to an overall lowering of salinity with depth. This salinity decrease, especially the chlorinity decrease, cannot be explained by conventional mechanisms such as the influx of and mixing of fresh water from the nearby continent, because of the observed increase of $\delta^{18} \mathrm{O}$ with depth, which reaches values of $+2.5 \%$ (SMOW). Similar chemical trends of pore-water composition occur on other continental margins and have been interpreted as resulting from the decomposition of gas hydrates (Hesse and Harrison, 1981).

Gas hydrates, like ice, exclude salt ions from their crystal structure. They also fractionate isotopes by preferentially withdrawing heavy isotopes of $\mathrm{H}, \mathrm{C}$, and $\mathrm{O}$ from the pore fluids. During burial and compaction, the solids, including the hydrate crystals, sink relative to the pore fluids. The hydrates carry isotopically heavy and fresh water to levels of decreased porosity at greater sub-bottom depths, leaving lighter isotopes, salts, and remaining pore fluids behind. Thawing of the hydrates at the base of the hydrate zone or during core recovery, and remixing with the smaller volumes of pore water that remain in the deeper subsurface levels, will decrease chlorinity and increase positive isotope values. The occurrence of gas hydrates may control the early diagenetic evolution of pore fluids. By causing downward freshening of the pore waters, a diagenetic regime may be established that is significantly different from that of hydrate free sediments. In the future this contrast in porewater composition could serve as a prospecting tool for hydrates.

None of the changes described for Sites 496 and 497 are observed in the pelagic and hemipelagic sediments of Site 495 , because their initial organic matter content of $1 \%$ to $2 \%$ is about half that of the mid-slope sites, and their sedimentation rates are less than the pore-fluid diffusion rate. Pore-water chemistry of this hole consequently does not show any appreciable variations with depth except for $\mathrm{Sr}^{2+}$ and dissolved $\mathrm{SiO}_{2}$. The latter occur in the pelagic chalk section and indicate carbonate recrystallization and porcellanite precipitation.

Chemical trends of pore waters from Trench Sites 499 and 500 show strong fluctuations between the sandy portions of turbidites and the intercalated silts and clays. Without the sand layers, however, vertical trends in porefluid composition would be similar to those observed in hydrate-free lower-slope Site 494 (Harrison et al., this volume).

In summary, the chemistry of the pore fluids of these young, Quaternary to Miocene sediments from the active margin off Guatemala provides some important clues as to the early diagenetic processes that are presently in progress. 


\section{PALEOGEOGRAPHY}

One of the most important targets of Leg 67 was the search for sediments comparable to those known on land in the Nicoya Complex of Costa Rica, whose northwestward prolongation to Guatemala is suggested by geophysical data (Ladd et al., 1978; Ibrahim et al., 1979). Unfortunately, the occurrence of high gas concentrations on the Trench slope prevented drilling deep enough sections to achieve this goal. The oldest formations recognized in the different sites of the slope were Upper Cretaceous (494), lower Miocene (496), and lower Pliocene (497). The most complete sequence from this continental margin was identified at Site 494, from bottom to top: Upper Cretaceous, middle Eocene, upper Oligocene-lower Miocene, Pliocene, and Pleistocene. This sequence, except for minor differences in thickness, is similar to the Esso Petroleum Well on the continental platform off Guatemala (Seely, 1979) and can also be compared, by ages more than by facies, with the sequence known on land along the Pacific coast of Nicaragua and Costa Rica.

These two sequences, at sea and on land, have one characteristic in common: both show an Upper Cretaceous unconformity at the base of the thick Tertiary deposits devoid of coarse volcanogenic detritus. The unconformity at Site 494, compared with those known on land, can be explained by the distance from the volcanic arc of south Central America. Thus the Tertiary sequence of Site 494 shows more distal, more abyssal facies than those of the Tertiary sequences in Nicaragua and Costa Rica, which are close to the source area for the volcanogenic detritus and may correspond to sedimentation in a fore-arc basin.

\section{CONCLUSIONS}

Shipboard visual and microscopic observations, and subsequent shore-based studies of Leg 67 samples, highlight the unexpected thickness and prevalence of the drape of hemipelagic sediment blanketing both the landward and the seaward slopes of the Middle America Trench at the Guatemala transect. An increase in grain size of terrigenous minerals from the early Miocene to Recent at the oceanic reference site suggests sedimentation by low-density suspension currents or nepheloid layers reaching hundreds of kilometers seaward of the Trench axis. A few missing radiolarian zones indicate erosion of surface sediment as Site 495 passed over the outer swell seaward of the Trench. Small reverse faults at Site 495 and 500 are attributed to soft-sediment deformation. In contrast, the stratigraphy of the eight holes drilled in the Trench axis documents normal faulting of the subducting plate and of its overburden of pelagic sediments and turbidites. Lithologic and age sequences are neither repeated nör teversed at any of our sites, and pure pelagic sediments are absent in all sites landward of the Trench axis. Displaced benthic foraminifers suggest downslope transport of the slope sediments by various mechanisms. Leg 67 drill sites did not reach an "accretionary prism" because either none exists off Guatemala or we failed to penetrate deep enough. If accretion of slivers of oceanic crust with pelagic sediments is taking place at the base of the slope, it is occurring in the 500 to 800 meters of rock not drilled between the master thrust separating the upper and lower plates and the bottom of Site 494 at about 400 meters sub-bottom depth.

Our results are suprising in that the drape of hemipelagic sediments and turbidites off Guatemala is thicker, gas hydrates more prevalent, and the "accretionary prism" more elusive than we anticipated.

\section{ACKNOWLEDGMENTS}

We thank Juliana Fenner, Glenn Shepherd, Greg Moore, and Johanna Resig for their readings of various versions of the manuscript.

\section{REFERENCES}

Arthur, M. A., Carson, B., and von Huene, R., 1980. Initial tectonic deformation of hemipelagic sediment at the leading edge of the Japan convergent margin. In Scientific Party, Init. Repts. DSDP, 56, 57, Pt. 1: Washington (U.S. Govt. Printing Office), 569-613.

Aubouin, J., von Huene, R., Azéma, J., Coulbourn, W. T., Cowan, D. S., Curiale, J. A., Dengo, G. A., Faas, R. W., Harrison, W., Hesse, R., Ladd, J. W., Muzylöv, N., Shiki, T., Thompson, P. R., and Westberg, J., 1979. Prémiers resultats des forages profonds dans le Pacifique au niveau de la fosse de Guatemala. C. R. Acad. Sci. Paris, 289:1215-1220.

Bein, A. and Fütterer, D., 1977. Texture and composition of continental shelf to rise sediments off the northwestern coast of Africa: An indication for downslope transportation. Meteor Forschungsergeb. Reihe C, 27:46-74.

Carr, M. J., Stoiber, R. F., and Drake, C. L., 1974. The segmented nature of some continental margins. In Burk, C. A., and Drake, C. L. (Eds.), The Geology of Continental Margins: New York (Springer-Verlag), pp. 105-114.

Coats, R. R., 1962. Magma type and crustal structure in the Aleutian arc. In MacDonald, G. A., and Kuno, H. (Eds.), Crust of the Pacific Basin: Am. Geophys. Union Monograph, 6:92-109.

Coulbourn, W. T., 1981. Tectonics of the Nazca Plate edge and the continental margin of western South America, $18^{\circ}$ to $23^{\circ} \mathrm{S}$ latitude. In Kulm, L. D., Hussong, D., Dymond, J., Dash, J., (Eds.), The Nazca Plate and Adjacent Southern American Margin: Boulder (Geol. Soc. Am.), pp. 587-618.

Coulbourn, W. T., and Moberly, R., 1977. Structural evidence of the evolution of forearc basins off South America. Can. J. Earth Sci., 14:102-116.

Dickinson, W. R., and Seely, D. R., 1979. Structure and stratigraphy of forearc regions. Bull. Am. Assoc. Pet. Geol., 63:2-31.

Drake, D. E., and Gorsline, D. S., 1973. Distribution and transport of suspended particulate matter in Hueneme, Redondo, Newport, and La Jolla submarine canyons, California. Bull. Geol. Soc. Am., 84:3949-3968.

Hesse, R., 1977. SOFTEX-radiographs of sliced piston cores from the Japan and southern Kurile Trench and slope areas. In Honza, E. (Ed.), Geol. Surv. Jpn. Cruise Rep., 7:86-108.

Hesse, R., Foreman, H. P., Forristall, G. Z., Heezen, B. C., Hekel, H., Hoskins, R. H., Jones, E. J. W., Kaneps, A. G., Krashenninikov, V. A., MacGregor, I., and Okada, H., 1974. Walther's facies rule in pelagic realm - a large-scale example from the Mesozoio-Cenozoic Pacific. Z. Dtsch. Geol. Ges., 125:151-172.

Hesse, R., and Harrison, W. E., 1981. Gas-hydrates (clathrates) causing pore-water freshening and oxygen isotope fractionation in deep-water sedimentary sections of the terrigenous continental margins. Earth Planet. Sci. Lett, 55:453-462.

Honza, E. 1980. Pre-Site survey of the Japan Trench transect, Deep Sea Drilling Project. In Scientific Party, Init. Reports DSDP, 56, 57, Pt. 2: Washington (U.S. Govt. Printing Office), 449-458.

Hussong, D. M., Uyeda, S., et al., 1982. Init. Repts. DSDP, 60: Washington, (U.S. Govt. Printing Office).

Hussong, D. M., Edwards, P. B., Johnson, S. H., Campbell, J. F., and Sutton, G. H., 1976. Crustal structure off the Peru-Chile Trench: $8^{\circ}-12^{\circ} \mathrm{S}$ latitude. In Sutton, G. H., Manghnani, M. H., 
Moberly, R., and McAffe, E. U. (Eds.), The Geophysics of the Pacific Ocean Basin and its Margin: A volume in honor of George P. Woollard: Washington (Am. Geophys. Union), 19:71-86.

Ibrahim, A. K., Latham, G. V., and Ladd, J., 1979. Seismic refraction and reflection measurements in the Middle America Trench offshore Guatemala. J. Geophys. Res., 84(B10):5643-5649.

Karig, D. E., Ingle, J. C., Jr., et al., 1975. Site 298. In Karig, D. E., Ingle, J. C., Jr. et al., Init. Reports DSDP, 31: Washington (U.S. Govt. Printing Office), 317-332.

Karig, D. E., and Sharman, G. F., 1975. Subduction and accretion in trenches. Bull. Geol. Soc. Am., 86:377-389.

Katz, H. R., 1971. Continental margin in Chile-its tectonic style conpressional or extensional? Am. Assoc. Pet. Geol. Bull., 55: 1753-1758.

Kulm, L. D., Schrader, H., Resig, J. M., Thornburg, T. M., Masias, A., and Johnson, L., 1981. Late Cenozoic carbonates on the Peru continental margin: lithostratigraphy, biostratigraphy, and tectonic history. In Kulm, L. D., Dymond, J., et al. (Eds.), Nazca Plate: Crustal Formation and Andean Convergence: Ann Arbor (Geol. Soc. Am. Memoir 154), pp. 469-508.

Kulm, L. D., von Huene, R., et al., 1973. Sites 175 and 181. In Kulm, L. D., von Huene, R., et al., Init. Reports DSDP, 18: Washington (U.S. Govt. Printing Office), $169-180$ and 449-500.

Ladd, J. W., Ibrahim, A. K., McMillen, K. J., Latham, G. V., von Huene, R. E., Watkins, J. S., Moore, J. C., and Worzel, J. L., 1978. Tectonics of the Middle America Trench. Int. Symp. Guatemalan Earthquake and Reconstruction Process, 1, Feb. 4th, 1976, Guatemala City, Guatemala.

Luyendyk, B. P., 1970. Origin and history of abyssal hills in the northeast Pacific Ocean. Bull. Geol. Soc. Am., 81:2237-2260.

McCave, I. N., 1972. Transport and escape of fine-grained sediment from shelf areas. In Swift, D. J. P., Duane, D. B., and Pilkey, O. H. (Eds.), Shelf Sediment Transport Process and Pattern: Stroudsberg, Pennsylvania (Dowden, Hutchinson, and Ross, Inc.), pp. $225-248$.

Minster, J. B., and Jordan, T. H., 1978. Present-day plate motions J. Geophys, Res., 83:5331-5354.

Moore. J. C., Watkins, J. S., Shipley, T. H., Bachman, S. B., Beghtel, F. W., Butt, A., Didyk, B. M., Leggett, J. K., Lundberg, N., McMillen, K. J., Niitsuma, N., Shephard, L. E., Stephan, J., and Stradner, H., 1979. Progressive accretion in the Middle America Trench, southern Mexico. Nature, 281:638-642.

Okada, H. 1980. Pebbles and carbonate nodules from Deep Sea Drilling Project Leg 56 Cores. In Scientific Party, Init. Repts.
DSDP, 56, 57, Pt. 2: Washington (U.S. Govt. Printing Office), 1089-1105.

Prince, R. A., Resig, J. M., Kulm, L. D., and Moore, T. C., Jr., 1974. Significance of uplifted turbidite basins on the seaward wall of the Peru Trench. Geology, 2:607-611.

Rea, D. K., 1975. Model for the formation of topographic features of the East Pacific Rise crest. Geology, 3:77-80.

Rona, P. A., Harbison, R. N., Bassinger, B. G., Scott, R. B., and Nalwalk, A. J., 1976. Tectonic fabric and hydrothermal activity of the Mid-Atlantic Ridge crest (Lat. $26^{\circ}$ N). Bull. Geol Soc. Am., 87: 661-674.

Scholl, D. W., Marlow, M. S., and Cooper, A. K., 1977. Sediment subduction and offscraping at Pacific margins. In Talwani, M. and Pitman, W. C., III (Eds.), Island Arcs, Deep Sea Trenches, and Back-arc Basins: Washington (Am. Geophys. Union), Maurice Ewing Ser. No. 1, pp. 199-210.

Sclater, J. G., Anderson, R. N., and Bell, M. L., 1971. Elevation of ridges and the evolution of the central eastern Pacific. J. Geophys. Res., 76:7888-7915.

Seely, D. R., 1979. The evolution of structural highs bordering major forearc basins. In Watkins, J. S., Montadert, L., and Dickerson, P. W. (Eds.), Geological and Geophysical Investigations of Continental Margins: Am. Assoc. Petl. Geol. Mem. 29:245-260.

Seely, D. R., Vail, P. R., and Walton, G. G., 1974. Trench slope model. In Burk, C. A., and Drake, C. L., (Eds.), The Geology of Continental Margins: New York (Springer-Verlag), pp. 249-260.

Seibold, E., 1976. German cruises to the continental margin of northwest Africa in 1975: general reports and preliminary results from Valdivia 10 and Meteor 39. Meteor Forschungsergeb. Reihe C., 25:47-80.

Shepherd, G. L., 1979. Shallow Crustal Structue and Marine Geology of a Convergence Zone, Northwest Peru and Southeast Ecuador [Ph.D. dissert.]. University of Hawaii, Honolulu.

von Huene, R., Aubouin, J., Azéma, J., Blackinton, G., Carter, J., Coulbourn, W., Cowan, D., Curiale, J., Dengo, C., Faas, R., Harrison, W., Hesse, R., Hussong, D., Ladd, J., Muzylöv, N., Shiki, T., Thompson, P., and Westberg, J., 1980. The DSDP MidAmerica Trench transect off Guatemala. Bull. Geol. Soc. Am., 91, Pt. 1:421-432.

Wada, H., Niitsuma, N., Nagasawa, K., and Okada, H., 1982. Deepsea carbonate nodules from the Middle America Trench area off Mexico, Deep Sea Drilling Project Leg 66. In Watkins, J. S., Moore, J. C., et al., Init. Repts. DSDP, 66: Washington (U.S. Govt. Printing Office), 453-474. 